\title{
A New Leipothrix Species (Acari: Acariformes: Eriophyoidea) from Hungary on Zinnia elegans (Asteraceae)
}

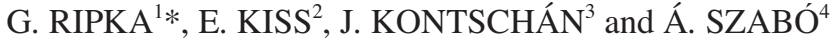 \\ ${ }^{1}$ National Food Chain Safety Office, Directorate of Plant Protection, \\ Soil Conservation and Agri-environment, H-1118 Budapest, Budaörsi út 141-145, Hungary \\ ${ }^{2}$ Plant Protection Institute, Szent István University, H-2100 Gödöllő, Páter Károly u. 1, Hungary \\ ${ }^{3}$ Plant Protection Institute, Centre for Agricultural Research, H-1525 Budapest, P.O. Box 102, Hungary \\ ${ }^{4}$ Department of Entomology, Faculty of Horticultural Science, Szent István University, \\ H-1118 Budapest, Villányi út 29-43, Hungary
}

(Received: 11 September 2020; accepted: 12 October 2020)

\begin{abstract}
A new vagrant species of phyllocoptine mites, Leipothrix nagyi $\mathbf{n}$. sp. collected from Zinnia elegans (Asteraceae) is described and illustrated from Hungary. Further three eriophyoid species were recorded for the first time in Hungary, viz. Aceria hippophaena (Nalepa, 1898) found on Hippophaë rhamnoides, Epitrimerus cupressi (Keifer, 1939) collected from Cupressus sempervirens and Epitrimerus tanaceti Boczek et Davis, 1984 associated with Tanacetum vulgare. The female of E. tanaceti is re-described, while the male and nymph are described for the first time.
\end{abstract}

Keywords: Eriophyidae, Leipothrix, common zinnia, Asteraceae, Hungary.

The large family Asteraceae (Compositae) contains 1,911 plant genera with 32,913 accepted species names (The Plant List, 2013). Representatives of the family Asteraceae are a dominant feature of the Hungarian flora with 267 recognised species. According to Király (2009) it amounts to $9.8 \%$ of the current vascular plants of Hungary. An extraordinary range of eriophyoids occupy the plants of this family. In Hungary, $8 \%$ of 384 currently known eriophyoid species live on asteraceous hosts (Ripka, 2007). So far, no eriophyoid species has been recorded on the representatives of the genus Zinnia.

Keifer (1966) erected the phyllocoptine genus Leipothrix (Acari: Acariformes: Eriophyidae) based on the following characters: basiventral femoral setae $b v$ being absent on both leg pairs and having a central longitudinal ridge on the opisthosoma. Amrine et al. (2003) completed the characters with the presence of moderately long and bifurcate dorsal palp genual setae $d$. One Leipothrix species is known from Hungary: Leipothrix polygalae (Farkas, 1968) from Polygala amara subsp. brachyptera (Ripka, 2013). Recently several Epitrimerus species were reassigned to the genus Leipothrix based on branched pedipalp genual setae $d$ and absence of femoral setae $b v$ (Chetverikov, 2005; Petanović and Rector, 
2007). Leipothrix species (including the former Fletchmannia spp. which are synonyms according to Amrine et al., 2003) are known from the representatives of several plant families (e.g. Asteraceae, Chloranthaceae, Cyperaceae, Dipsacaceae, Pontederiaceae, Rubiaceae, Sinopteridaceae and Urticaceae) in North and South America, Asia, Africa and Europe (Davis et al., 1982; Amrine and Stasny, 1994; Amrine et al., 2003; Chetverikov, 2005; Petanović and Rector, 2007; Tan et al., 2016).

\section{Materials and Methods}

The eriophyoid mite fauna of different herbaceous and woody plant species was studied from plant samples collected in Budapest and different counties of Hungary, between 2013 and 2019. The plant material (including leaves, petioles, stems, buds, flowers and fruits) was collected and placed in plastic bags by E. Kiss, G. Ripka, J. Kontschán and Á. Szabó, then taken to the laboratory and examined under a stereo dissecting microscope (Zeiss Stemi 2000-C, Germany). Eriophyoid mites found were placed directly into $88 \%$ lactic acid with the aid of a bent insect pin. After clearing the specimens in lactic acid at room temperature, the mites were placed into Keifer's F-medium with sorbitol on microscope slides (Keifer, 1975). The slide preparations were dried and then sealed with commercial nail varnish (Upton, 1991). Specimens were examined with the aid of a research phase contrast compound microscope (Nikon Eclipse E600, Japan) equipped with a drawing tube (Nikon Y-IDT, Japan).

The generic classification follows Amrine et al. (2003), and comparisons were also made with new genera described since that publication. The terminology of external morphology and setal notation adopted for the morphological description follows mainly Lindquist (1996). The number of measured specimens (n) is given within parentheses in the description. All measurements of mites were made according to Amrine and Manson (1996) using an ocular micrometre eyepiece and are given in micrometres $(\mu \mathrm{m})$. Measurements and means are rounded off to the nearest integer, when necessary. All measurements, unless specified otherwise, are lengths. In the description, each measurement of the holotype precedes the corresponding range for the paratypes. Range values are given in parentheses except in cases of constant value. For re-described females the mean and ranges, for males and immature stages, only the ranges are given.

The names of the plant taxa are used according to Király (2009).

Drawing abbreviations follow Amrine et al. (2003): AD. Prodorsal shield; AL. Lateral view of anterior body region; CG. Female coxigenital region; em. Empodium; LO. Lateral view of annuli; L1. Leg I (foreleg); PM. Lateral view of posterior opisthosoma.

The holotype and paratype slide mounts of the new species are deposited in the collection of the Directorate of Plant Protection, Soil Conservation and Agri-environment, National Food Chain Safety Office, Budapest, Hungary. 


\section{TAXONOMY \\ Family Eriophyidae Nalepa \\ Subfamily Phyllocoptinae Nalepa \\ Genus Leipothrix Keifer \\ Leipothrix nagyi Ripka et Kiss n. sp.}

(Fig. 1)

Type species: Leipothrix solidaginis Keifer, 1966: 1-3.

Description. Female - Body fusiform, 197 (172-220, n = 8), 69 (69-80) wide, 75 (73-76) thick. Gnathosoma 27 (25-29), projecting obliquely downwards; chelicerae 18 (17-21); dorsal, palp genual setae $d$ considerably long and angled, 21 (18-22), in part bifurcate, branch 1 (no variation), at 5 (4-5) from the base of setae $d$; pedipalp coxal setae ep 2 (2-3), pedipalp tarsal seta $v 2$ (1-2). Prodorsal shield 67 (67-71) including frontal lobe, 67 (67-72) wide, subsemicircular, with a frontal lobe 12 (12-13) over gnathosomal base and granules, ventral edge of lobe serrate in lateral view because of the 5-6 thin
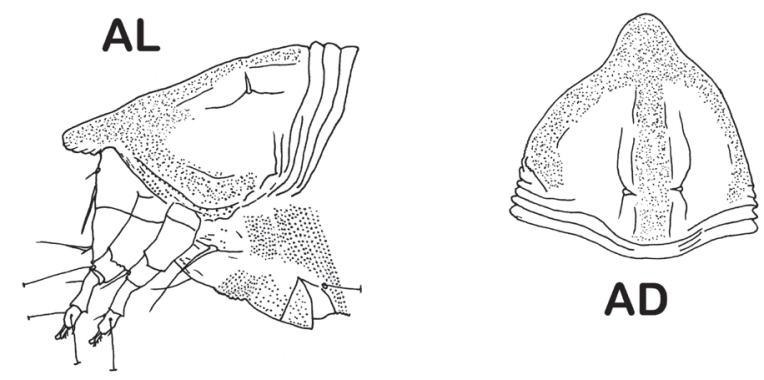

AD
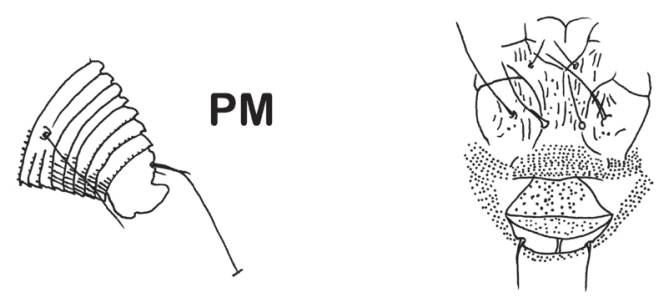

CG
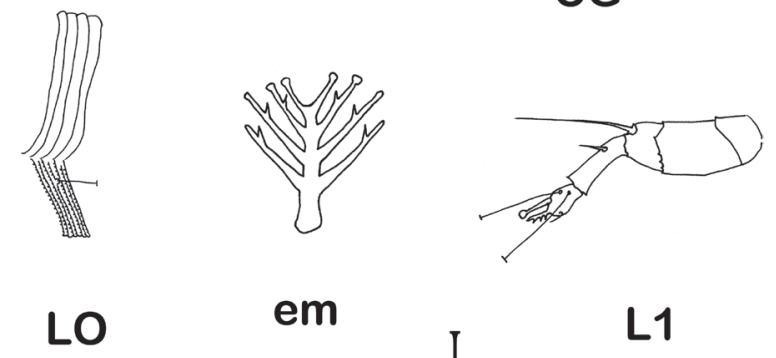

em

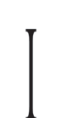

L1

Fig. 1. Leipothrix nagyi n. sp., semischematic drawings. Scale bar: $22 \mu \mathrm{m}$ for AL; $25 \mu \mathrm{m}$ for AD; $19 \mu \mathrm{m}$ for $\mathbf{C G} ; 22 \mu \mathrm{m}$ for $\mathbf{L O} ; 15 \mu \mathrm{m}$ for $\mathbf{L} \mathbf{1} ; 24 \mu \mathrm{m}$ for PM; $3 \mu \mathrm{m}$ for em. 
ridges ventrally bearing tiny round microtubercles; shield pattern consists of two faint, incomplete admedian lines beginning close to posterior margin of the shield, slightly diverging to rear margin, and a faint, short, incomplete submedian line along the tubercles of setae $s c$; median line absent. Prodorsal shield covered by dotting, punctate. Tubercles of setae sc 12 (12-14) ahead of rear shield margin, 15 (15-17) apart, setae sc 5 (4-5), directed up and projecting centrad. Epicoxal area with 5-6 thin ridges bearing tiny round microtubercles which reach the tip of frontal lobe. Subcapitular (suboral) plate cordate.

Legs with all usual segments present. Leg I 42 (42-46), femur 12 (12-13), basiventral femoral setae $b v$ absent, genu 7 (6-7), antaxial genual setae $l$ " 36 (36-38), tibia 11 (10-12), paraxial tibial setae $l^{\prime}$ located at 1/3 (1/4-1/3) from dorsal base, $5(3-5)$, very fine, tarsus 7 (7-8), paraxial, unguinal, tarsal setae $u^{\prime} 3$ (3-4), paraxial, fastigial, tarsal setae $f t^{\prime}$ 19 (15-21), antaxial, fastigial, tarsal setae $f t$ " 25 (25-27), tarsal solenidion $\omega 5$ (5-6), with prominent knob, empodium simple, bilaterally symmetrical, 5 (5-6), with 4 paired rays.

Leg II 40 (40-43), femur 13 (13-15), basiventral femoral setae $b v$ absent, genu 7 (no range), antaxial genual setae $l " 10$ (8-10) very fine, tibia 10 (8-10), tarsus 7 (6-7), paraxial, unguinal, tarsal setae $u^{\prime} 2$ (2-3), paraxial, fastigial, tarsal setae $f t^{\prime} 3$ (3-5), antaxial, fastigial, tarsal setae $f t " 25$ (23-25), tarsal solenidion $\omega 5$ (no range), with prominent knob, empodium simple, bilaterally symmetrical, 5 (5-6), with 4 paired rays. Minute spinules distally on femora and tibiae on both leg pairs.

Coxisternum I and coxisternum II with few faint, longitudinal lines, dashes and granules; setae $1 b 12$ (10-13), tubercles $1 b 13$ (12-14) apart, setae $1 a 19$ (18-20), tubercles $1 a 8$ (8-10) apart, setae $2 a 37$ (37-47) very fine, tubercles $2 a 22$ (22-23) apart. Prosternal apodeme 12 (10-12). Coxigenital area with 11 (9-12) very narrow semiannuli bearing tiny, round microtubercles before epigynium.

Opisthosoma with a middorsal and two subdorsal ridges. Middorsal ridge shorter than subdorsal ones. 47 (44-49) smooth dorsal semiannuli, 2 specimens with very faint microtubercles on rear annular margins, 75 (71-78) microtuberculate ventral semiannuli, dorsal opisthosoma evenly arched. Small, oval microtubercles on rear annular margins ventrally, elongate on rear 5-6 annuli. Opisthosomal setae c2 25 (22-25), 55 (52-59) apart, on annulus 12 (10-13); setae $d 38$ (38-40), 37 (36-40) apart, on annulus 28 (26$32)$; setae $e 16$ (16-18), 17 (17-20) apart, on annulus 52 (47-54); setae $f 33$ (33-40), 25 (23-25) apart, on annulus 70 (65-73), or 5-6 from rear. Setae $h_{2} 67$ (67-72), 10 (8-10) apart; in part bifurcate and angled, branch 1 (no variation), at 8 (8-9) from the base of setae $h 2$, setae $h 12$ (2-3), 5 (5-6) apart, very thin. Caudal lobe slightly bends upward.

External genitalia 17 (17-22), 23 (23-24) wide. Female genital coverflap at base with granules, longitudinal lines of granules 10 (10-12); setae $3 a 15$ (13-15), 15 (13-15) apart.

MALE unknown.

NYMPH - White, vermiform, $160(\mathrm{n}=1), 66$ thick. Gnathosoma 25; dorsal palp genual setae $d 8$, pedipalp coxal setae ep 2, pedipalp tarsal seta $v$ not detectable; chelicerae 16. Prodorsal shield 50, 53 wide, subsemicircular, with a frontal lobe 4 over gnathosomal base. Setae sc 3, directed up. Epicoxal area with tiny round granules. Leg I 25, femur 7, basiventral femoral setae $b v$ absent; genu 3, antaxial genual setae $l$ " 27; tibia 6; paraxial tibial setae $l$ ' located at $1 / 3$ from dorsal base, 1 , very fine; tarsus 3 , solenidion $\omega 5$, distally knobbed; empodium simple, bilaterally symmetrical, 4, with 3 paired rays. Leg II 23, femur 5, basiventral femoral setae $b v$ absent; genu 3, antaxial genual setae $l$ " 3, 
very fine; tibia 5; tarsus 3 , solenidion $\omega 4$, distally knobbed; empodium simple, bilaterally symmetrical, 4, with 3 paired rays. Setae $1 b 3$, setae $1 a 7$, setae $2 a 13$. Opisthosoma with 52 dorsal, 56 ventral semiannuli. Between the longitudinal lines of tubercles of setae $s c$ or between the subdorsal ridges, the dorsal annuli smooth. Laterally and the ventral semiannuli with minute microtubercles on rear annular margins. Rear 4 dorsal annuli with tiny microtubercles on rear annular margins, and elongate ventrally. Setae $c 25$, on annulus 13; setae $d 12$, on annulus 23; setae $e 9$, on annulus 35; setae $f 17$, on annulus 51 , or 5 from rear. Setae $h 11$; setae $3 a 3$.

Host plant - Common zinnia, Zinnia elegans L. (Asteraceae); an annual ornamental plant from Mexico.

Relation to the host plant - The leaf vagrant mite was found on the upper side and underside of the leaves. No damage was caused.

Type locality - Romhány, Nógrád county (Northern Hungary), 47.925828 N, 19.257382 E, $167 \mathrm{~m}$ above sea level. The host plant species, Z. elegans, grows in a garden.

Type material - Holotype female among 6 females and 1 nymph (slide \# 1488a), coll. Enikő Kiss, 29. ix. 2019. Paratypes: 3 females and 1 nymph (slide \# 1488c), and 4 females (slide \# 1488b) coll. E. Kiss. Deposited in the Directorate of Plant Protection, Soil Conservation and Agri-environment, National Food Chain Safety Office, Budapest, Hungary.

Etymology - The species is named in honour of the late Dr. Barnabás Nagy (19212020), who was an eminent entomologist and ecologist. The gender is feminine.

Differential diagnosis and remarks - So far, no eriophyoid species has been recorded on the representatives of the genus Zinnia. The new species described herein shows similarities with Leipothrix solidaginis Keifer living on Solidago californica (Keifer, 1966), however the latter has many lines and dashes forming netlike pattern on the prodorsal shield (apparently prodorsal shield with two faint, incomplete admedian lines, and two faint, incomplete submedian lines in L. nagyi n. sp.), heavily lined coxal surface (whereas coxisternum I-II with faint, longitudinal lines and dashes in L. nagyi n. sp.), elongate microtubercles on dorsal ridge (dorsal annuli smooth in L. nagyi n. sp.); sternal line absent (versus prosternal apodeme present in L. nagyi n. sp.), 57 long prodorsal shield (apparently 67-71 in L. nagyi n. sp.), body 66 wide and 50 thick (whereas 70-80 and 73-76, resp. in L. nagyi n. sp.), rather short leg I (37) and leg II (35) (whereas 42-46, and 40-43, resp. in L. nagyi n. sp.), and the length of opisthosomal setae $c 2$ and setae $f$ in L. solidaginis 13 and 25 (whereas 22-25 and 33-40, resp. in L. nagyi n. sp.). It should be noted that Keifer (1966) did not describe and illustrate the shape of dorsal palp genual setae $d$, but later they have been mentioned as prominent and bifurcate (Baker et al., 1996; Amrine et al., 2003).

\section{Epitrimerus tanaceti Boczek et Davis, 1984}

(Figs 2-5)

Epitrimerus tanaceti - Boczek and Davis, 1984: 200-203.

Epitrimerus tanaceti - Amrine and Stasny, 1994: 657.

Re-description. Female - Body spindle form, $167(159-177, \mathrm{n}=4), 72$ (70-73) wide, 67 (67-68) thick. Gnathosoma 25 (23-27), projecting obliquely downwards; dorsal palp genual setae $d 10$ (8-11), unbranched; pedipalp coxal setae ep 4 (3-5); pedipalp tar- 
sal setae $v 2$ (1-2). Chelicerae 19 (18-20). Prodorsal shield 52 (49-58), 46 (40-53) wide, subsemicircular with blunt frontal lobe 8 (6-10). Shield pattern composed of two faint, incomplete admedian lines, diverging posteriorly, more widely separate on rear $1 / 3$, two faint, incomplete submedian lines; median line absent. Small granules between submedian lines and shield margin. Ornamentation of prodorsal shield is considerably variable, e.g. size of admedian and submedian lines, and the shield design weakly expressed. Tubercles of scapular setae sc 7 (6-7) ahead of rear shield margin, 25 (25-26) apart, setae $s c$ 7 (7-8), directed up and projecting centrad.

Legs with all usual segments and setae present. Leg I 36 (33-38), femur 12 (11-12), basiventral femoral seta $b v 9$ (8-12), genu 5 (no range), antaxial genual seta $l$ " 26 (25-27), tibia $9(8-10)$, paraxial tibial seta $l$ ' located at $1 / 2(2 / 5-1 / 2)$ from dorsal base, $4(4-5)$, very thin, tarsus 7 (6-8), unguinal tarsal setae $u^{\prime} 3$ (no range); solenidion $\omega 7$ (5-7), distally knobbed, slightly curved; empodium simple, bilaterally symmetrical, 6 (5-6), 4-rayed, with additional secondary branches. Leg II 33 (30-35), femur 11 (10-12), basiventral femoral seta $b v 10$ (9-12), genu 5 (no range), antaxial genual seta $l$ " 6 (5-6) very thin, tibia 7 (6-7), tarsus 6 (5-6), unguinal tarsal setae $u^{\prime} 2$ (2-3); solenidion $\omega 6$ (6-7), distally knobbed, slightly curved; empodium simple, bilaterally symmetrical, 6 (5-6), 4-rayed, with additional secondary branches. (Figs 2-4).

Coxigenital area with 7 (6-8) microtuberculate semiannuli. Coxisternae I and II with few, faint lines; anterior seta on coxisternum I, $1 b 7$ (7-8), tubercles setae $1 b 12$ (12-13) apart, proximal seta on coxisternum I, la 19 (15-22), tubercles setae $1 a 10$ (910) apart, proximal seta on coxisternum II, $2 a 43$ (41-45), tubercles setae $2 a 26$ (25-27) apart. Subcapitular (suboral) plate small and rounded, without distinct ornamentation. Prosternal apodeme 8 (8-9).

Opisthosoma with a middorsal and two subdorsal ridges, 44 (42-46) smooth dorsal, 60 (55-64) microtuberculate ventral semiannuli. Small microtubercles ventrally on rear

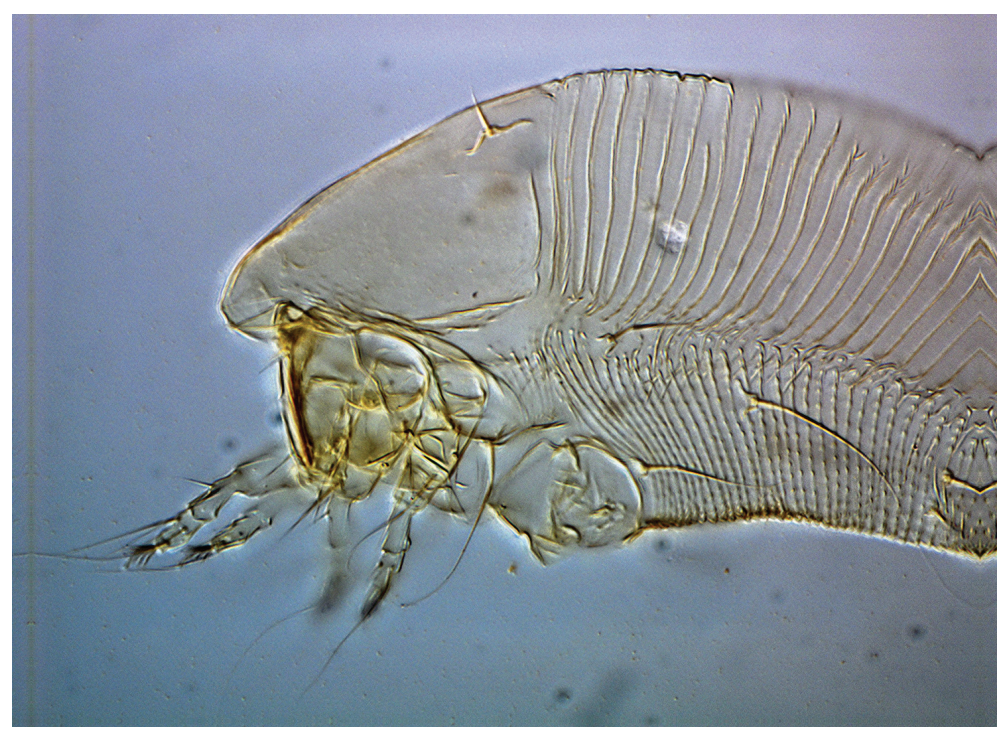

Fig. 2. Digital micrograph of Epitrimerus tanaceti, anterior part of female in lateral view. (Photo: Árpád Szabó) 
annular margin. Last 5-6 ventral annuli with linear microtubercles. Opisthosomal setae c2 24 (23-25), on annulus 8 (6-10), 53 (53-55) apart; opisthosomal setae $d 49$ (48-50), on annulus 21 (19-23), 31 (30-37) apart; opisthosomal setae e 20 (19-22), on annulus 38 (35-43), 16 (15-16) apart; opisthosomal setae $f 21$ (20-23), on annulus 56 (51-60), or 5

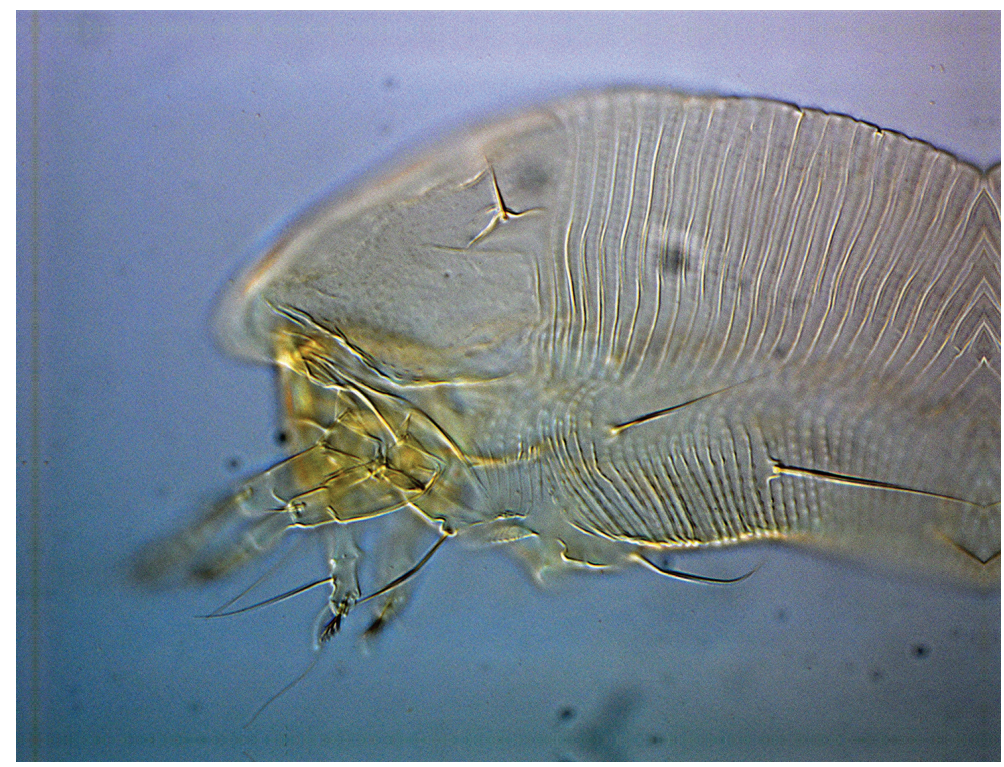

Fig. 3. Digital micrograph of Epitrimerus tanaceti, anterior part of female in lateral view. (Photo: Árpád Szabó)

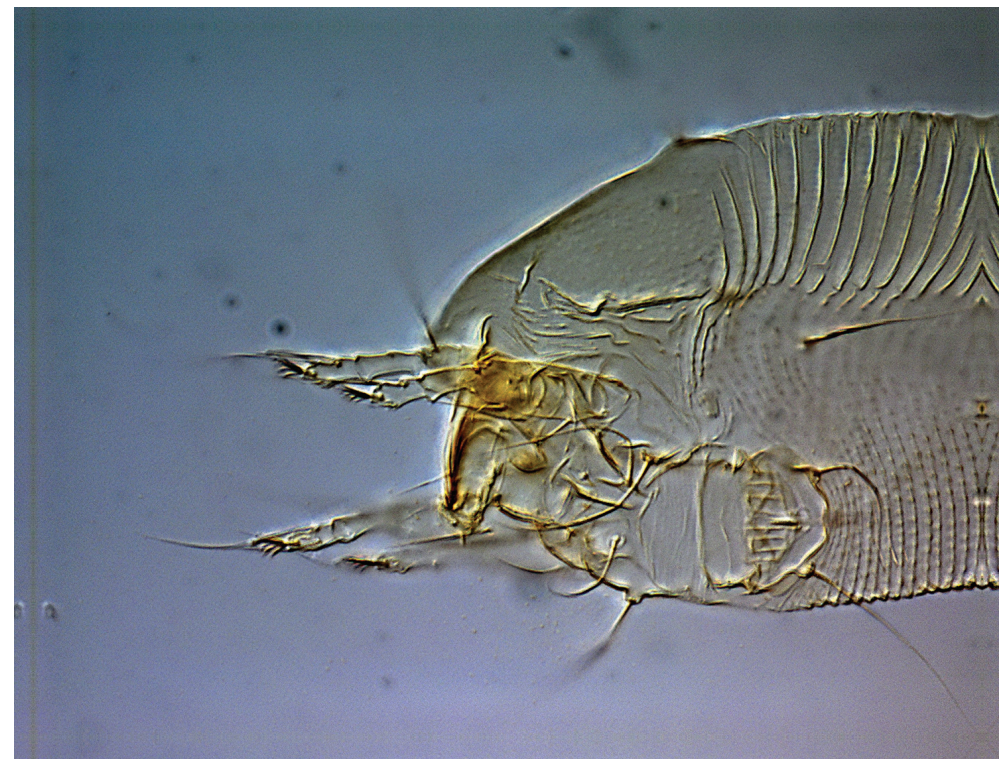

Fig. 4. Digital micrograph of Epitrimerus tanaceti, gnathosoma, legs and coxigenital region of female in ventrolateral view. (Photo: Árpád Szabó) 
(4-5) from the rear, 19 (19-20) apart. Setae $h 273$ (70-75), very thin at apex, 10 (9-10) apart; setae $h 13$ (3-5), 7 (6-8) apart. Anal lobes normal. (Fig. 5)

Genital plate 17 (15-20), 22 (20-25) wide. Female genital coverflap with 9 (8-10) longitudinal ridges; coxisternal III setae $3 a 15$ (14-15) apart, 30 (26-35), very thin.

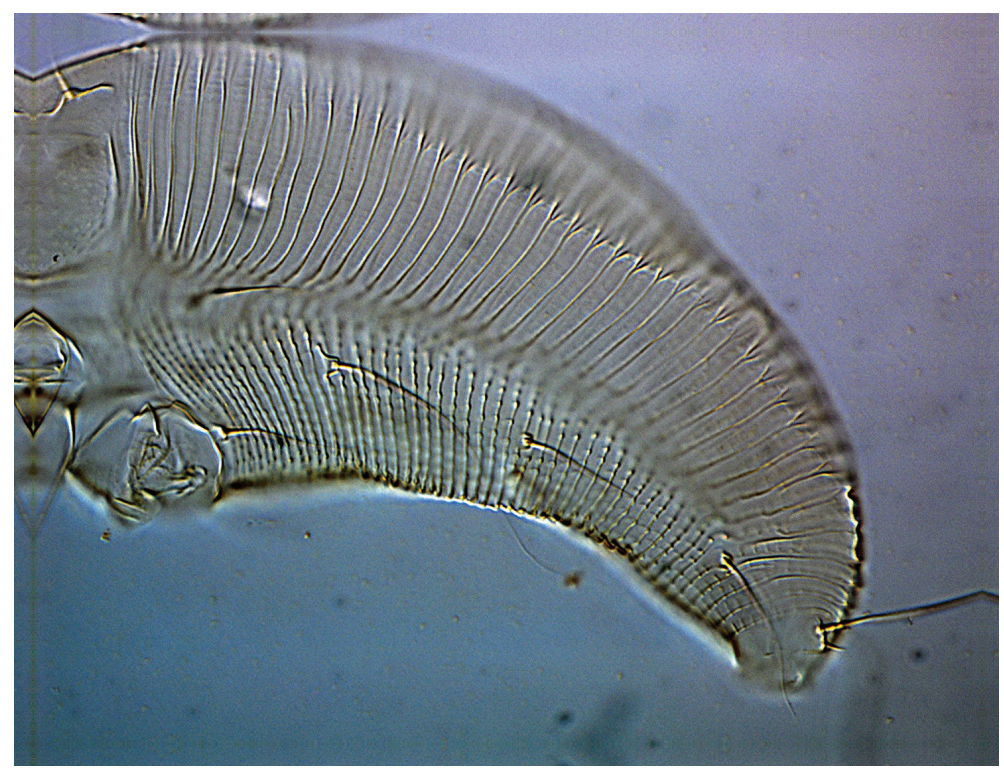

Fig. 5. Digital micrograph of Epitrimerus tanaceti, posterior part of female in ventrolateral view. (Photo: Árpád Szabó)

MALE - Similar to female, 140-148 $(\mathrm{n}=2), 62-63$ thick. Gnathosoma 25-27, projecting obliquely downwards; motivator discernible, 0.5 ; dorsal palp genual setae $d 6$ (5-6), pedipalp coxal setae ep 2-3; pedipalp tarsal setae $v$ 1-2. Prodorsal shield 52-53, 48-50 wide, subsemicircular, with blunt frontal lobe 6-7, ornamentation similar to female. Tubercles of scapular setae sc 6-7 ahead of rear shield margin, setae $s c 7$ (no range), directed up and projecting centrad. Minute granules situated in 3-4 lateral rows on epicoxal areas. Leg I 30-31, femur 9 (no range), basiventral femoral setae $b v 8-9$, very fine, genu 4 (no range), antaxial genual setae $l$ " 22-23, tibia 6-7, paraxial tibial setae $l$ ' located at 2/5-1/2 from dorsal base, 4 (no range), very fine, tarsus 5 (no range), solenidion $\omega$ 5-6, slightly curved, distally knobbed; empodium simple, bilaterally symmetrical, 5 (no range), 4-rayed. Leg II 27-28, femur 7-8, basiventral femoral setae $b v$ 7-8, very fine; genu 3-4, antaxial genual setae $l " 4$ (no range), very fine; tibia 5 (no range), tarsus 4-5; solenidion $\omega 5$ (no range), slightly curved, distally with a minute knob; empodium simple, bilaterally symmetrical, 4-5, 4-rayed. Coxisternae I and II with few dim lines; setae $1 b 6-7$, setae $1 a 12-13$, setae $2 a$ 22-24, all very fine. Subcapitular (suboral) plate small and anteriorly rounded, without distinct ornamentation. Coxigenital area with 7-8 microtuberculate semiannuli. Opisthosoma with 38-41 smooth dorsal, 50-53 microtuberculate ventral annuli. Very faint and elongate microtubercles laterally, smaller, denser ones ventrally on rear annular margins, except for 4 ventral annuli of anal lobes, which are elongate and linear. Caudal lobe normal in size and shape. Setae $c 217-19$, on ventral 
annulus 8-9; setae $d 30-32$, on ventral annulus 17-18; setae $e$ 14-15, on ventral annulus 31-32; setae $f 16-17$, on ventral annulus 46-49, or 4 from rear. Setae $h 271-73$; setae $h 1$ $1-2$. Genitalia $10-12$, posterior $1 / 2$ with minute granules, setae $3 a 15-17$, in progenital chamber tiny eugenital setae present.

NYMPH - Fusiform, $150(\mathrm{n}=1), 61$ wide. Gnathosoma 15; dorsal palp genual setae $d 4$; chelicerae 12. Prodorsal shield 40, 50 wide. Tubercles of setae sc 5 ahead of rear shield margin, 18 apart, setae sc 5, pointing up and diverging. Leg I 25, leg II 22. Setae $1 b$ 3, 10 apart, setae $1 a 7$ apart, setae $2 a 19$ apart. Opisthosoma with 54 dorsal, 55 ventral annuli. Dorsal and ventral annuli with well discernible, minute microtubercles on rear annular margins. Setae $c 2$ 9, on annulus 12, 46 apart; setae $d 16$, on annulus 23, 30 apart; setae $e$ 12, on annulus 35, 17 apart; setae $f 15$, on annulus 50, or 5 from rear, 19 apart. Setae $h 29$ apart; setae $h 11,5$ apart; setae $3 a 8,6$ apart.

Host plant - Tansy, Tanacetum vulgare L. (Asteraceae). Tansy is native to Hungary living in different plant associations, e.g. flood plain, wet fallow, and a segetal weed in field crops.

Relationship to the host - This mite caused no discernible symptoms on the host. The mite was found on the underside of the leaves. It is a new under surface leaf vagrant species for the fauna of Hungary.

Hungarian locality - Kétbodony, Nógrád county (Northern Hungary), by the roadside, 47.930022 N, 19.283616 E, 159 m elev.

Material examined - The re-described and illustrated female, the described male among 3 females (slide \# 1490a), 29. ix. 2019, coll. Enikő Kiss. Other specimens were collected by E. Kiss in the same locality and time, one slide (\# 1490b, with described male and nymph) was prepared from this material containing 1 male and 1 nymph from the leaves of the same plant. Slides are in the corresponding author's collection and deposited in the Directorate of Plant Protection, Soil Conservation and Agri-environment, National Food Chain Safety Office, Budapest, Hungary.

\section{Remarks}

There are some morphometric differences between the examined Hungarian Epitrimerus tanaceti specimens and the original description by Boczek and Davis (1984). We especially draw attention to the location of the microtubercles on the dorsal annuli: in the type specimens they are present on the first three dorsal annuli behind the prodorsal shield margin and in three bands on the middorsal and subdorsal ridges, whereas all dorsal annuli smooth in the specimens collected in Hungary. We also note that E. tanaceti has some design on the prodorsal shield, e.g. two incomplete admedian and two incomplete submedian lines (but they are indistinct on the majority of the examined specimens). The length of setae $h 2$ (22 in holotype of E. tanaceti) significantly differs from that of the Hungarian specimens (70-75). Nevertheless the examined specimens belong to E. tanaceti because the vast majority of the morphometric data for female matches the original description by Boczek and Davis (1984).

The following two species are new for the fauna of Hungary as well: 
Aceria hippophaena (Nalepa, 1898), Hippophä̈ rhamnoides L. (Elaeagnaceae), Gödöllö (Pest county, Central Hungary), coll. Géza Ripka, 2. vii. 2019. The mite was found on the lower side of the leaves. No damage was observed.

Epitrimerus cupressi (Keifer, 1939), Cupressus sempervirens L. (Cupressaceae), Budapest, distr. II, coll. Géza Ripka, 24. vi. 2019. Females and males of the species were collected from the young shoots and round and green cones of Italian cypress. No damage was observed.

\section{New records:}

Acaricalus cerriquerci Petanović et Vidović, Achaetocoptes quercifolii Farkas, Coptophylla cerriquerci Farkas, Quercus cerris L. (Fagaceae), Cserépfalu (Borsod-Abaúj-Zemplén county), coll. Dr. György Csóka, 9. ix. 2015. Mixed population of the three species were collected from the upper side and underside of the leaves. No damage symptom was visible.

Acaricalus cerriquerci Petanović et Vidović, Achaetocoptes quercifolii Farkas, Coptophylla cerriquerci Farkas, Quercus cerris L. (Fagaceae), Mátrafüred (Heves county), coll. Dr. György Csóka, 14. ix. 2015. The three species were collected in mixed population from both sides of the leaves. No damage was observed.

Aceria artemisiae (Canestrini), Artemisia vulgaris L. (Asteraceae), Kétbodony (Nógrád county), coll. Enikő Kiss, 29. ix. 2019. It was collected from the underside of the leaves.

Aceria macrochela (Nalepa), Acer campestre L. (Aceraceae), Budapest, distr. XI, coll. G. Ripka, 22. x. 2015. The mites caused tiny, bead leaf galls with 1-2 mm in diameter on the upper side of the leaves.

Aceria macrocheluserinea (Trotter), Acer campestre L. (Aceraceae), Budapest, distr. XI, coll. G. Ripka, 22. x. 2015. It was collected from the concave brownish erinea on the upper side of the leaves. Opposite to the erineum on the underside of the blade became convex.

Aceria salviae (Nalepa), Salvia sp. (Lamiaceae), Villány (Baranya county), coll. J. Kontschán, 5. vii. 2019. The species caused small leaf galls.

Aculops allotrichus (Nalepa), Robinia pseudoacacia L. (Fabaceae), Mosonmagyaróvár (Győr-Moson-Sopron county), coll. Dr. László Érsek, 10. vi. 2017, and Gödöllő (Pest county), coll. Enikő Kiss, 26. vi. 2017. The species was found on the underside of the leaflets, causing deformations.

Aculus ligustri (Keifer), Ligustrum ovalifolium Hassk. (Oleaceae), Eger (Heves county), coll. Ms. Ágnes Schmidt, 19. v. 2020. The species caused silvering, yellowing and rusting of the leaves.

Anthocoptes hungaricus Ripka, Hippophaë rhamnoides L. (Elaeagnaceae), Gödöllő (Pest county), coll. Enikő Kiss, 26. vi. 2017, 7. ix. 2018, and G. Ripka, 2. vii. 2019. Females and males were collected from the underside of the leaves. The vagrant, orange ochre mites caused no damage on the host plant.

Anthocoptes salicis Nalepa, Aceria salicis (Murray), Aculus tetanothrix (Nalepa) and Stenacis palomaris Keifer, Salix alba L. cv. Tristis (Salicaceae), Budapest, distr. XI, coll. G. Ripka, 15. viii. 2019. Mixed population of the four species were collected from the shoots, between the base of petioles and buds, the upper and lower side of the leaves. No symptom was observed. 
Eriophyes mali Nalepa, Malus domestica Borkh. (Rosaceae), Szár (Fejér county), coll. Á. Szabó, 23. vii. 2018. The mite was found under the epidermis on the lower side of the leaves, and caused brownish blisters and erineum on both sides of the leaves.

Eriophyes pyri (Pagenstecher), Pyrus pyraster (L.) Burgs. (Rosaceae), Gödöllő (Pest county), coll. Enikő Kiss, 26. vi. 2017, and Vászoly (Veszprém county), coll. G. Ripka, 10. vi. 2019. The leaf margin rolled up to the upper side due to the mite feeding. E. pyri was collected from the upper side of the leaves and co-occurred with tydeid and tarsonemid mites in this cramped microhabitat.

Phyllocoptes goniothorax (Nalepa), Crataegus monogyna Jacq. (Rosaceae), Vászoly (Veszprém county), coll. G. Ripka, 9. vii. 2017. The mite was collected from the underside of the leaves. It rolled down the leaf margins to the lower side of the leaf and caused hyaline then brownish erineum on inner surface.

Quadracus urticarius (Canestrini et Massalongo), Urtica dioica L. (Urticaceae), Bercel (Nógrád county), coll. Enikő Kiss, 8. xi. 2019. The vagrant species was collected from the underside of the leaves. No damage symptom was visible.

Rhinophytoptus dudichi Farkas, Cerasus vulgaris Mill. (Rosaceae), Budapest, distr. IV, coll. Enikö Kiss, 6. ix. 2018. The vagrant mite was collected from the underside of the leaves. No damage was observed.

Tegonotus acutilobus (Nalepa), Cornus sp. (Cornaceae), Budapest, distr. XI, coll. Dr. László Érsek, 28. vii. 2017. It is a leaf vagrant mite, with no visible damage.

Tegonotus depressus (Nalepa), Corylus colurna L. (Corylaceae), Budapest, distr. II, coll. G. Ripka, 6. viii. 2013. The vagrant mite was collected from the underside of the leaves and caused no damage.

\section{Acknowledgements}

The authors are indebted to: Dr. György Csóka (Mátrafüred), Dr. László Érsek (Budapest) and Ms. Ágnes Schmidt (Eger) for providing their leaf samples collected from Quercus cerris, and Robinia pseudoacacia, and Cornus sp., and Ligustrum ovalifolium, resp., Mr. Balázs Herzog (National Food Chain Safety Office, Budapest) for his assistance in preparing the drawings. This study was supported by the ÚNKP-19-3-I-SZIE-16 New National Excellence Program of the Ministry for Innovation and Technology, by 2019-2.1.11-TÉT-201900027 project, the EFOP-3.6.3- VEKOP-16-2017-00008 project and by the Ministry for Innovation and Technology within the framework of the Higher Education Institutional Excellence Program (NKFIH-1159-6/2019) in the scope of plant breeding and plant protection research of Szent István University. The project was co-financed by the European Union and the European Social Fund.

\section{Literature}

Amrine, J. W. Jr. and Manson, D. C. M. (1996): Preparation, mounting and descriptive study of eriophyoid mites. In: E. E. Lindquist, M. W. Sabelis and J. Bruin (eds): Eriophyoid Mites - Their Biology, Natural Enemies and Control. World Crop Pests, 6. Elsevier Scientific Publishing, Amsterdam, pp. 383-396.

Amrine, J. W. Jr. and Stasny, T. A. (1994): Catalog of the Eriophyoidea (Acarina: Prostigmata) of the World. Indira Publishing House, West Bloomfield, pp. ix +798.

Amrine, J. W. Jr., Stasny, T. A. H. and Flechtmann, C. H. W. (2003): Revised Keys to World Genera of Eriophyoidea (Acari: Prostigmata). Indira Publishing House, West Bloomfield, iv +244 pp. 
Baker, E. W., Kono, T., Amrine, J. W., Jr., Delfinado-Baker, M. and Stasny, T. A. (1996): Eriophyoid mites of the United States. Indira Publishing House, West Bloomfield, USA. pp. ix +394.

Boczek, J. and Davis, R. (1984): New species of eriophyid mites (Acari: Eriophyoidea). Florida Entomologist, 67, 198-213.

Chetverikov, P. E. (2005): Eriophyid mites (Acari: Eriophyoidea: Eriophyidae) of the genus Leipothrix Keifer, 1966 from sedges (family Cyperaceae L.). Acarina, 13, 145-154.

Davis, R., Flechtmann, C. H. W., Boczek, J. H. and Barké, H. E. (1982): Catalogue of Eriophyid Mites (Acari: Eriophyoidea). Warsaw Agricultural University Press, Warsaw, 254 p.

Farkas, H. (1968): On the eriophyoids of Hungary VI. The description of three new species. Annales Historico-Naturales Musei Nationalis Hungarici, Pars Zoologica. 60, 239-241.

Keifer, H. H. (1939): Eriophyid Studies VII. Bulletin of the Department of Agriculture State of California, 484-505.

Keifer, H. H. (1966): Eriophyid Studies B-19. Bureau of Entomology, California Department of Agriculture, $1-20$.

Keifer, H. H. (1975): Eriophyoidea Nalepa. In: L. R. Jeppson, H. H. Keifer and E. W. Baker (eds): Mites Injurious to Economic Plants. University of California Press, Berkeley, Los Angeles, London. pp. 327-533.

Király, G. (ed.) (2009): Új magyar füvészkönyv. Magyarország hajtásos növényei. Határozókulcsok. [New Hungarian Herbal. The Vascular Plants of Hungary. Identification Key.]. Aggteleki Nemzeti Park Igazgatóság, Jósvafö, 616 p.

Lindquist, E. E. (1996): External anatomy and notation of structures. In: E. E. Lindquist, M. W. Sabelis and J. Bruin (eds): Eriophyoid Mites - Their Biology, Natural Enemies and Control. World Crop Pests, 6. Elsevier Scientific Publishing, Amsterdam, pp. 3-31. [The Netherlands]

Nalepa, A. (1898): Das Tierreich. Eine Zusammenstellung und Kennzeichnung der rezenten Tierformen. 4. Lieferung. Acarina. Eriophyidae (Phytoptidae). Berlin, ix $+74 \mathrm{p}$.

Petanović, R. U. and Rector, B. G. (2007): A new species of Leipothrix (Acari: Prostigmata: Eriophyidae) on Dipsacus spp. in Europe and reassignment of two Epitrimerus spp. (Acari: Prostigmata: Eriophyidae) to the genus Leipothrix. Annals of the Entomological Society of America, 100, 157-163.

Ripka, G. (2007): Checklist of the eriophyoid mite fauna of Hungary (Acari: Prostigmata: Eriophyoidea). Acta Phytopathol. et Entomol. Hung., 42, 59-142.

Ripka, G. (2013): Redescription of Leipothrix polygalae (Farkas, 1968) n. comb. from Hungary (Acari: Prostigmata: Eriophyoidea). Acta Phytopathol. et Entomol. Hung., 48, 143-148.

Tan, M.-C., Kontschán, J. and Wang, G.-Q. (2016): Two new species of the genus Leipothrix Keifer, 1966 (Acari: Eriophyidae: Phyllocoptinae) from China. Annals of the Entomological Society of America, 109, $663-668$.

The Plant List (2013): Version 1.1. Published on the Internet; http://www.theplantlist.org/ (accessed 28th May 2020)

Upton, M. S. (1991): Methods for Collecting, Preserving, and Studying Insects and allied forms. Misc. Publ. No. 3. The Australian Entomological Society, Brisbane, $v+86$ pp.

Open Access statement. This is an open-access article distributed under the terms of the Creative Commons Attribution 4.0 International License (https://creativecommons.org/licenses/by/4.0/), which permits unrestricted use, distribution, and reproduction in any medium, provided the original author and source are credited, a link to the CC License is provided, and changes - if any - are indicated. (SID_1) 